\title{
KAJIAN TERHADAP KARAKTERISTIK PERPINDAHAN PANAS PADA LOOP THERMOSYPHON SEBAGAI ALAT RECOVERY PANAS TEMPERATUR RENDAH
}

\author{
Saloom Hilton Siahaan ${ }^{1}$, Parulian Siagian ${ }^{2}$, Lestina Siagian ${ }^{3}$ \\ Fakultas Teknik Mesin Universitas HKBP Nommensen Pematang Siantar \\ Email: parulian.nommensen@gmail.com, saloomhsiahaan@gmail.com
}

\begin{abstract}
The purpose of this study was to examine the effectiveness of the Loop Thermosyphon Heat Exchanger (LTHE) fluidized R134a refrigerant at variations in working fluid pressure of $0.8 \mathrm{MPa}$ and 1.2MPa. Thermosyphon is made of three parts, namely, evaporator, condenser and adiabatic part. Evaporators are made of 3/4 inch diameter copper pipe with a length of $3.5 \mathrm{~cm}$. The condenser is made of 3/4 inch diameter copper pipe with a length of $15 \mathrm{~cm}$. The adiabatic part of the steam line is made of copper pipes with a diameter of $3 / 4$ inches and a length of 25 $\mathrm{cm}$ and a liquid line with a diameter of $3 / 8$ inches with a length of $27 \mathrm{~cm}$. Things that were investigated included the effect of air flow velocity (heated fluid) of $0.8 \mathrm{~m} / \mathrm{s}, 1 \mathrm{~m} / \mathrm{s}$, and $1.2 \mathrm{~m} / \mathrm{s}$ on the effectiveness of LTHE and the effect of an increase in evaporator temperature by $40^{\circ} \mathrm{C}$, $50^{\circ} \mathrm{C}$, and $60^{\circ} \mathrm{C}$ on the effectiveness of LTHE. The study was conducted experimentally where the LTHE evaporator was heated with a heater. The results of this study show that the effectiveness of LTHE heat transfer work pressure of 1.2 MPa pressure is about $30-68 \%$ and higher than the effectiveness of LTHE heat transfer work pressure of $0.8 \mathrm{MPa}$ pressure about 22-35\%. Effectiveness decreases with increasing airflow velocity. The LTHE thermal resistance of $0.8 \mathrm{MPa}$ pressure is around $0.3-0.45^{\circ} \mathrm{C} / \mathrm{W}$ and is greater than the LTHE thermal resistance of $1.2 \mathrm{MPa}$ pressure around $0.08-0.4^{0} \mathrm{C} / \mathrm{W}$.
\end{abstract}

Keywords: Thermosyphon Loop, Heat Exchanger, R134a Refrigerant, Effectiveness, Thermal Resistance.

\section{PENDAHULUAN}

\subsection{Latar Belakang Masalah}

Seiring dengan melonjaknya jumlah permintaan energi maka perlu adanya pemanfaatan energi seoptimal mungkin guna pencegahan krisis energi agar tidak semakin meningkat. Kebutuhan untuk penghematan energi telah menjadi salah satu aspek yang mulai diperhitungkan dalam perekonomian suatu industri. Satu sarana menghemat energi adalah dengan memanfaatkan sebagian dari energi dalam aliran limbah yang panas dengan menggunakan alat recovery panas energi untuk memanaskan lebih dulu fluida yang lebih dingin. Dengan metode ini berarti pemanfaatan limbah energi hasil produksi digunakan kembali sehingga tidak ada energi yang terbuang ke lingkungan. Pada industri pengeringan misalnya, panas buangan setelah proses pengeringan belum dimanfaatkan secara optimal. Hal ini menyebabkan energi yang dibutuhkan untuk proses pengeringan menjadi besar karena limbah panas terbuang begitu saja. Padahal udara buangan dari proses pengeringan masih memiliki kandungan energi yang dapat dimanfaatkan lagi dalam proses pengeringan. Begitu pula pada peralatan lain seperti Air Conditioner (AC) dan Freezer, limbah panas yang 
dikeluarkan tidak termanfaatkan lagi. Salah satu jenis peralatan recovery panas yang menarik dikembangkan adalah berjenis Thermosyphon.

Adapun keuntungan menggunakan thermosyphon sebagai penukar kalor adalah karena:

1. Mudah dan fleksibel dalam pembuatan karena hanya terdiri dari dua komponen utama, yaitu wadah (pipa) yang tertutup rapat dan fluida kerja.

2. Mudah dalam perawatan. Thermosyphon tidak memerlukan perawatan mekanis karena tidak ada bagian yang bergerak yang dapat rusak.

3. Penukar kalor bersifat ekonomis. Alat ini tidak memerlukan masukan tenaga (daya pompa atau kompresor) dalam pengoperasian dan bebas dari pelumasan dan pendinginan.

4. Thermosyphon membutuhkan daya fan lebih rendah dan meningkatkan efisiensi panas sistem secara keseluruhan.

Oleh karena itu penelitian tentang thermosyphon perlu dikembangkan terutama untuk recovery panas pada temperatur rendah. Pemilihan pada temperatur rendah sangat menarik karena banyak panas yang dibuang pada temperatur yang tidak terlalu tinggi misalnya pada peralatan pengering dan kondensor mesin pendingin.

Penelitian ini dilakukan dengan menguji thermosyphon pada saluran udara dengan variasi temperatur evaporator (heat source) thermosyphon, tekanan fluida kerja dalam thermosyphon, dan kecepatan udara untuk mengetahui unjuk kerja thermosyphon pada masing-masing variasi.

\subsection{Perumusan Masalah}

Dalam penelitian dirumuskan beberapa permasalahan yang yaitu:

1. Bagaimanakah karakteristik perpindahan panas pada penukar kalor jenis loop thermosyphon dengan variasi temperatur evaporator (heat source) thermosyphon terhadap efektivitas perpindahan panas dan hambatan termalnya.

2. Bagaimanakah karakteristik perpindahan panas pada penukar kalor jenis loop thermosyphon dengan variasi kecepatan aliran udara dalam thermosyphon terhadap efektivitas perpindahan panasnya.

3. Bagaimanakah karakteristik perpindahan panas pada penukar kalor jenis loop thermosyphon dengan variasi tekanan fluida kerja terhadap efektivitas perpindahan panasnya.

\subsection{Batasan Masalah}

Pada penelitian ini masalah dibatasi sebagai berikut ini:

1. Alat penukar kalor berupa loop thermosyphon dimana:

a. Pada bagian evaporator berdiameter $3 / 4$ inchi dengan panjang $3,5 \mathrm{~cm}$.

b. Pada bagian adiabatik (vapour line) berdiameter 3/4 inchi dan panjangnya $25 \mathrm{~cm}$.

c. Pada daerah kondenser berdiameter $3 / 4$ inchi dengan panjang $15 \mathrm{~cm}$. 


\section{d. Pada daerah adiabatik liquid line berdiameter 3/8 inchi dengan panjang 27 $\mathrm{cm}$.}

2. Pipa kalor terbuat dari pipa tembaga sebagai pipa selubung dan refrigeran R134a sebagai fluida kerjanya. Fluida kerja R-134a diisikan pada tekanan 0,8 MPa dan 1,2 MPa

3. Arah aliran udara dalam saluran udara (duct) adalah aliran menyilang (crossflow) terhadap arah aliran fluida kerja pipa kalor.

4. Panas Evaporator pipa kalor bersumber dari arus listrik yang dialirkan pada lilitan kawat nikelin berdiameter 0,5 mm sejumlah 25 lilitan sepanjang 3,5 cm.

5. Daerah evaporator, daerah adiabatik (vapor line maupun liquid line) pada thermosyphon dan daerah saluran udara ( $d u c t)$ diisolasi.

6. Fluida yang dipanasi thermosyphon adalah udara yang dialirkan oleh blower.

7. Saluran uji (duct) berbentuk balok berongga dengan lebar $\mathrm{x}$ tinggi pada permukaan bagian dalam adalah $12 \mathrm{~cm}$ x $12 \mathrm{~cm}$. Panjang saluran $147 \mathrm{~cm}$.

8. Jumlah pembacaan temperatur yang akan diamati pada pengujian ini adalah enam titik yaitu dua pada bagian kondenser thermosyphon, dua pada evaporator thermosyphon, satu pada saluran udara sebelum melewati thermosyphon, dan satu pada saluran udara setelah melalui thermosyphon.

9. Karakteristik perpindahan panas yang diteliti hanya meliputi efektivitas dan hambatan termal.

\subsection{Tujuan dan manfaat}

Penelitian ini bertujuan untuk:

1. Mengetahui karakteristik perpindahan panas pada alat penukar kalor jenis loop thermosyphon dengan variasi temperatur evaporator thermosyphon terhadap efektivitas perpindahan panas dan hambatan termalnya.

2. Mengetahui karakteristik perpindahan panas pada alat penukar kalor jenis loop thermosyphon dengan variasi kecepatan aliran udara pada saluran udara (duct) terhadap efektivitas perpindahan panasnya.

3. Mengetahui karakteristik perpindahan panas pada penukar kalor jenis loop thermosyphon dengan variasi tekanan fluida kerja di dalam tabung thermosyphon terhadap efektivitas perpindahan panasnya.

Hasil penelitian yang didapat diharapkan memberi manfaat sebagai berikut:

1. Memberikan pengetahuan tentang karakteristik perpindahan panas loop thermosyphon yang terbuat dari pipa selubung tembaga dan fuida kerja berupa refrigeran R-134a sebagai alat recovery panas temperatur rendah.

2. Hasil penelitian ini dapat diterapkan pada industri pengeringan maupun industri yang memanfaatkan alat recovery panas sebagai alat penukar kalor yang fleksibel, murah, ekonomis dalam penggunaanya (tidak memerlukan pompa, 
kompresor, ataupun peralatan lain untuk menggerakkan fluida kerja), dan mudah dalam perawatannya.

\section{TINJAUAN PUSTAKA}

Meng-Chang Tsai, dkk (2007) melakukan penelitian pada loop thermosyphon, dengan methanol sebagai fluida kerja. Evaporator yang digunakan dalam studi ini memiliki diameter dalam $25 \mathrm{~mm}$ dan tinggi dari $25 \mathrm{~mm}$. Tiga evaporator, tanpa struktur (wick) dan berstruktur (wick) dengan lebar mesh $1 \mathrm{~mm}$ dan $4 \mathrm{~mm}$. Percobaan dilakukan di bawah kondisi $20^{\circ} \mathrm{C}, 30^{\circ} \mathrm{C}, 40^{\circ} \mathrm{C}$ dan $50^{\circ} \mathrm{C}$ air pendingin, untuk pemanas menggunakan daya listrik dari 20 sampai $150 \mathrm{~W}$, fluida kerja dengan rasio pengisian metanol 5\%, 10\%, 20\%, 30\%, 40\% dan 50\%. serta laju aliran air pendingin 0,2 1/menit. Hasil pengujian variasi dari suhu evaporator sebagai fungsi dari beban panas (Watt) untuk 3 jenis evaporator dengan rasio pengisian 10\%, didapat bahwa suhu evaporator terendah pada evaporator dengan ketebalan $1 \mathrm{~mm}$ sumbu struktur (wick). Temperatur evaporator tertinggi pada evaporator tanpa sumbu struktur (wick), dengan daya listrik pemanas sebesar $150 \mathrm{~W}$ pada suhu $70,5^{\circ} \mathrm{C}$, sedangkan suhu untuk pada evaporator dengan ketebalan $1 \mathrm{~mm}$ struktur sumbu $63,5^{\circ} \mathrm{C}$.

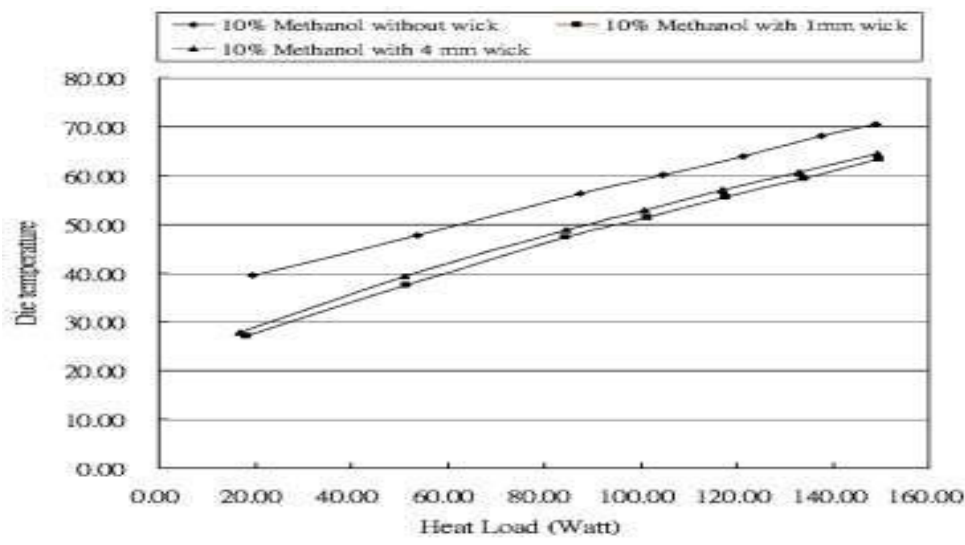

Gambar 2.1. Grafik perbandingan suhu evaporator berstruktur (wick) dengan tanpa wick (Meng-Chang Tsai, dkk, 2007)

Meena P., dkk (2006) melakukan penelitian terhadap recovery panas pada siklus pengeringan dengan $C L O H P / C V$ (Closed-loop oscillating heat-pipe with check valves) air-preheater yang digunakan sebagai recovery panas buangan. CLOHP/CV heatexchanger terdiri dari pipa dengan panjang 3,58 $\mathrm{m}$ dan diameter dalamnya 0,002 $\mathrm{m}$. Evaporator dan kondensor memiliki panjang 0,19 m, bagian adiabatik sepanjang 0,08 $\mathrm{m}$, kecepatan udara $0,5,0,75$, dan $1,0 \mathrm{~m} / \mathrm{s}$ dengan temperatur udara panas 50,60 , dan $70^{\circ} \mathrm{C}$. Temperatur udara panas naik dari $50^{\circ} \mathrm{C}$ menjadi $70^{\circ} \mathrm{C}$ dan terjadi peningkatan perpindahan panas. Peningkatan kecepatan dari $0,5 \mathrm{~m} / \mathrm{s}, 0,75 \mathrm{~m} / \mathrm{s}, 1,0 \mathrm{~m} / \mathrm{s}$ menjadikan efektivitas menurun. Pada kenaikan temperatur udara panas dari $50^{\circ} \mathrm{C}$ ke $70^{\circ} \mathrm{C}$ 
efektivitas meningkat. Efektivitas perpindahan panas tertinggi dicapai pada kecepatan udara $0,5 \mathrm{~m} / \mathrm{s}$ dan temperatur $70^{\circ} \mathrm{C}$ sebesar 0,75 .

Meena, P. dan Rittidech, S. (2008) melakukan penelitian untuk membandingkan unjuk kerja perpindahan panas dari closed-looped oscillating heat pipe and closed-looped oscillating heat pipe with check valves heat exchangers dengan fluida R134a, ethanol dan air sebagai fluida kerjanya. Pipa kalor terbuat dari pipa tembaga dengan diameter dalam 2,03 mm, 40 belokan dengan masing-masing panjang evaporator, adiabatik, dan kondensor adalah 20, 10, dan $20 \mathrm{~cm}$. Fluida kerja diisikan dalam pipa pada rasio pengisian 50\%. evaporator dipanasi dengan heater dan kondensor didinginkan dengan udara, sedangkan pada bagian adiabatik diisolasi. Dari hasil pengujian didapatkan kesimpulan bahwa unjuk kerja perpindahan panas closedlooped oscillating heat pipe with check valves heat exchanger lebih baik dari pada closed-looped oscillating heat exchanger dengan fluida kerja R134a sebesar 0,65.

Suyitno dan Thoharudin (2009) melakukan penelitian secara eksperimen pipa kalor dengan variasi panjang pipa, diameter pipa dan fluida kerja pipa kalor. Pada salah satu ujung pipa kalor diberi pemanas dengan heater $50 \mathrm{~W}$ dan pada ujung pipa kalor kedua diberi sirip dan dialiri udara dengan kecepatan $0,1 \mathrm{~m} / \mathrm{s}$ dengan temperatur kamar. Dari penelitian ini diperoleh hasil bahwa efektivitas perpindahan panas pipa kalor sekitar 23\% dan jauh lebih tinggi dari efektivitas perpindahan panas pipa biasa sebesar 13\%. Efektivitas perpindahan panas pada pipa kalor berfluida etanol-air akan meningkat seiring dengan peningkatan kadar etanol. Pemakaian pipa yang berdiameter lebih besar mampu memberikan efektivitas perpindahan panas yang lebih besar.

\subsection{Pengertian Pipa Kalor dan Thermosyphon}

Thermosyphon merupakan salah satu jenis alat penukar kalor pipa kalor. Dalam operasi thermosyphon, uap membawa sejumlah besar panas laten dari evaporator ke kondensor. Thermosyphon dapat dibagi menjadi tiga bagian yaitu, evaporator dimana pada bagian tersebut panas dimasukkan dalam sistem, kondensor dimana pada bagian tersebut panas dilepaskan dari sistem, dan bagian adiabatik dimana pada daerah tersebut tidak ada panas yang masuk maupun keluar sistem dan sebagai jalur uap dan cairan mengalir. Ketika panas masuk sistem, fluida kerja dalam evaporator thermosyphon akan terpanasi hingga menjadi uap membawa kalor laten menuju daerah kondensor thermosyphon dan melepaskan kalor tersebut sehingga menjadi cairan kembali untuk selanjutnya mengalir menuju kondenser. Thermosyphon sebenarnya merupakan heat pipe tetapi tanpa struktur kapiler (wick) (Sabharwall P, 2009)

Received May $4^{\text {th }}$, 2020; Revisea

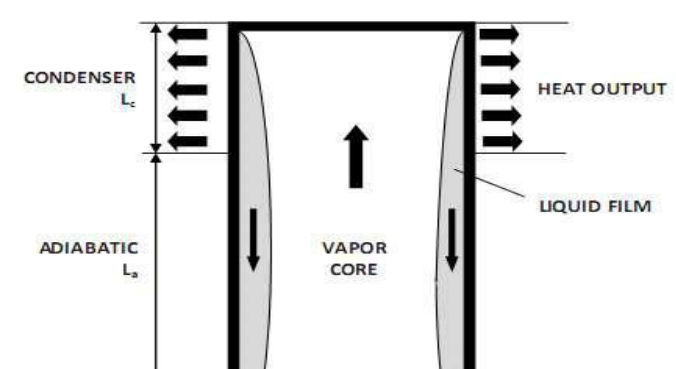




\section{Gambar 2.2. Thermosyphon (Sabharwall P, 2009)}

Menurut Meyer A, Dobson, R T (2006) thermosyphon merupakan heat pipe tetapi tanpa struktur kapiler (wick), perbedaan antara thermosyphon dan heat pipe yaitu thermosyphon menggunakan gaya gravitasi untuk mentransfer panas dari sumber panas (heat source) yaitu evaporator yang terletak di bawah kondensor. Di evaporator fluida kerja menguap dan berdasarkan perbedaan massa jenis dan tekanan uap fluida tersebut mengalir ke atas ke bagian kondensor. Akibat dari pendinginan di kondensor, fluida kerja tersebut kemudian mengembun di bagian kondensor dan mengalir kembali ke bagian evaporator di bawah pengaruh gravitasi. Menurut penelitian sebelumnya diperoleh kesimpulan bahwa gaya gravitasi pada thermosyphons mempunyai efek perpindahan panas yang lebih baik dibandingkan dengan struktur kapiler (wick) dalam heat pipe karena struktur wick cenderung menambah hambatan terhadap aliran kondensat.

\subsection{Tipe Thermosyphon}

Berdasarkan temperatur operasinya thermosyphon dapat dibedakan menjadi dua tipe thermosyphon, yaitu:

1. Open Thermosyphon

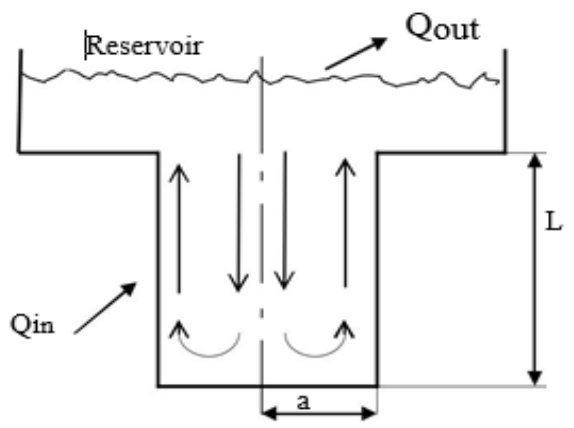

Gambar 2.3. Open thermosyphon ( Irvine,F.T, Hartnett P.J, 1973)

Open thermosyphon adalah sebuah pipa kalor yang terbentuk dari sebuah tabung yang tertutup pada pada salah satu ujungnya.

2. Closed Thermosyphon

Received May $4^{\text {th }}$, 2020; Revised June $8^{\text {th }}$, 2020; Accepted June $10^{\text {th }}$, 2020 
Closed Thermosyphon adalah sebuah pipa kalor yang terbentuk dari sebuah tabung yang tertutup pada kedua ujungnya.

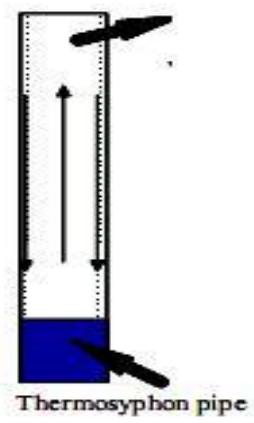

Gambar 2.4. Closed thermosyphon ( Irvine,F.T, Hartnett P.J, 1973)

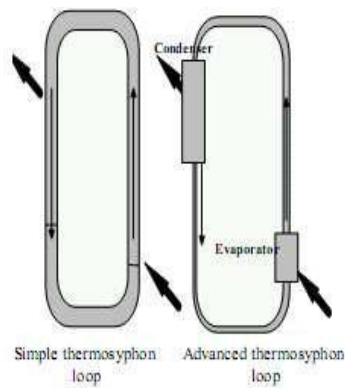

Gambar 2.5. Loop thermosyphon ( Irvine,F.T, Hartnett P.J, 1973)
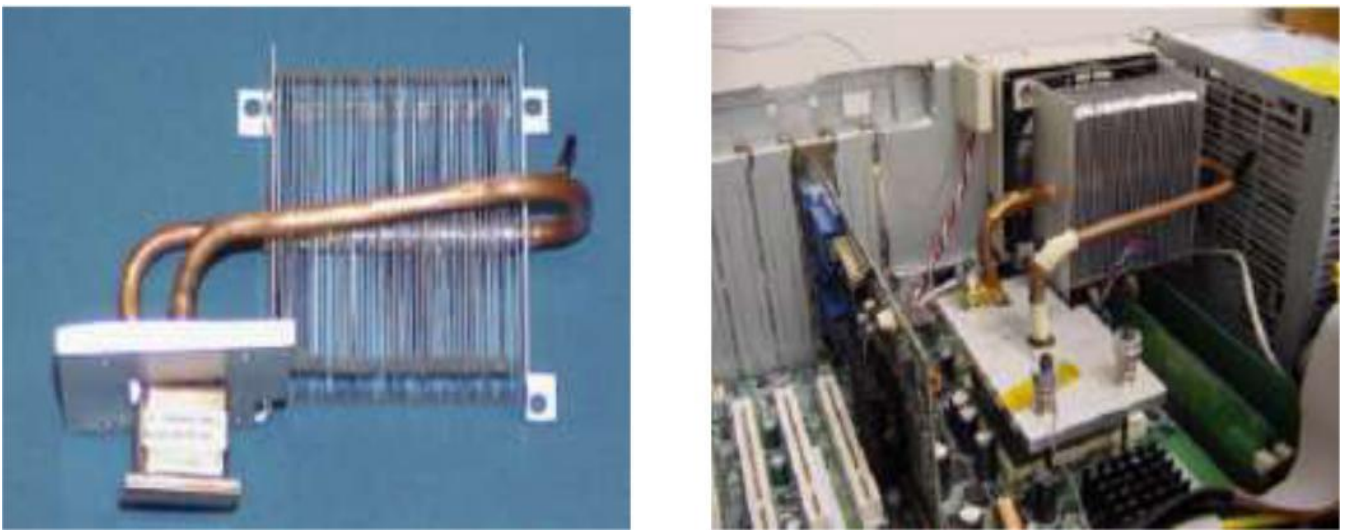

Gambar 2.6. Contoh aplikasi loop thermosyphon (Pal, A., Joshi, Y., Beitelmal, A. H., Patel, C. D. and Wenger, T, 2002)

\subsubsection{Fluida Kerja}

Fluida kerja yang dioperasikan pada thermosyphon ditentukan berdasarkan temperatur operasinya. Tabel 2.1 memperlihatkan beberapa fluida kerja berdasarkan temperatur operasinya.

Tabel 2.1. Fluida kerja thermosyphon 


\begin{tabular}{|c|c|c|c|c|}
\hline $\begin{array}{l}\text { Working } \\
\text { Fluid }\end{array}$ & $\begin{array}{c}\text { Triple } \\
\text { Point } \\
(\mathbf{K})\end{array}$ & $\begin{array}{c}\text { Critic } \\
\text { al } \\
\text { Point } \\
\text { (K) }\end{array}$ & $\begin{array}{c}\text { Useful } \\
\text { Range } \\
\text { (K) }\end{array}$ & Literature \\
\hline Oxigen & 54,3 & 154,8 & $55-154$ & Bejan, A., Kraus, A.D., 2003 \\
\hline Nitrogen & 63,1 & 126,2 & $65-125$ & $\begin{array}{c}\text { Bejan, A., Kraus, A.D., } \\
2003\end{array}$ \\
\hline Ethane & 134,8 & 425,0 & $260-350$ & $\begin{array}{c}\text { Bejan, A., Kraus, A.D., } \\
2003\end{array}$ \\
\hline Methanol & 175,2 & 513,2 & $273-503$ & $\begin{array}{c}\text { Bejan, A., Kraus, A.D., } \\
2003\end{array}$ \\
\hline Toluene & 178,1 & 593,9 & $275-473$ & $\begin{array}{c}\text { Bejan, A., Kraus, A.D., } \\
2003\end{array}$ \\
\hline Acetone & 180,0 & 508,2 & $250-475$ & $\begin{array}{c}\text { Bejan, A., Kraus, A.D., } \\
2003\end{array}$ \\
\hline Ammonia & 195,5 & 405,6 & $200-405$ & $\begin{array}{c}\text { Bejan, A., Kraus, A.D., } \\
2003\end{array}$ \\
\hline Mercury & 234,3 & 176,3 & $280-1070$ & $\begin{array}{c}\text { Bejan, A., Kraus, A.D., } \\
2003\end{array}$ \\
\hline Water & 273,2 & 647,3 & $273-643$ & $\begin{array}{c}\text { Bejan, A., Kraus, A.D., } \\
2003\end{array}$ \\
\hline $\begin{array}{c}\text { Potassiu } \\
m\end{array}$ & 336,4 & 2500 & $400-1800$ & $\begin{array}{c}\text { Bejan, A., Kraus, A.D., } \\
2003\end{array}$ \\
\hline Lithium & 453,7 & 3800 & $500-2100$ & $\begin{array}{c}\text { Bejan, A., Kraus, A.D., } \\
2003\end{array}$ \\
\hline Silver & 1234 & 7500 & $1600-2400$ & $\begin{array}{c}\text { Bejan, A., Kraus, A.D., } \\
2003\end{array}$ \\
\hline $\mathrm{R}-134 \mathrm{a}$ & 169,7 & 373,9 & $\begin{array}{l}\text { Tergantung } \\
\text { tekanan }\end{array}$ & $\begin{array}{c}\text { http://encyclopedia.airliqui } \\
\text { de.com }\end{array}$ \\
\hline Etanol & 150 & 514 & - & http://en.wikipedia.org \\
\hline
\end{tabular}

\subsection{Karakteristik Perpindahan Panas}

\section{Efektivitas Perpindahan Panas}

Meena, P., S. Rittidech menghitung efektivitas perpindahan panas ( $\varepsilon$ ) pada pipa kalor dengan rumus

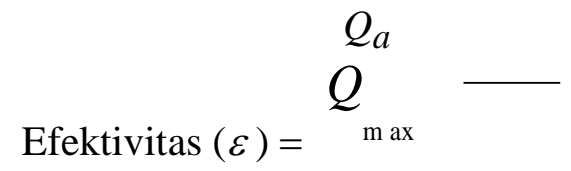


Dimana $\mathrm{Q}_{\mathrm{a}}$ merupakan laju perpindahan panas aktual sedang $\mathrm{Q}_{\max }$ merupakan laju perpindahan panas maksimum yang bisa terjadi pada evaporator. Laju perpindahan panas aktual terjadi pada saluran uji dengan fluida kerja udara pada temperatur kamar. Sehingga kalor yang diserap udara $\left(\mathrm{Q}_{\mathrm{a}}\right)$ pada kondenser dapat dihitung dengan :

$$
Q_{a}=m_{a} c_{p a} \Delta T
$$

dan

$$
m_{a}=\rho_{a} v_{a} A
$$

Dimana $: m_{a} \quad$ : laju aliran massa udara $(\mathrm{kg} / \mathrm{s})$

$\mathrm{c}_{\mathrm{pa}} \quad$ : kalor jenis udara $(\mathrm{J} / \mathrm{kgK})$

$\Delta T \quad$ : beda temperatur sebelum dan sesudah pipa kalor $(\mathrm{K})$

$\rho_{a}:$ massa jenis udara $\left(\mathrm{kg} / \mathrm{m}^{3}\right)$

A : luas penampang saluran $\left(\mathrm{m}^{2}\right)$

$v_{a}:$ kecepatan aliran udara $(\mathrm{m} / \mathrm{s})$

Laju perpindahan maksimum terjadi pada thermosyphon merupakan daya listrik pada elemen pemanas karena input panas (heater) berasal dari aliran listrik. Jouhara H. dkk (2008) menuliskan input panas merupakan perkalian tegangan listrik dengan arus listrik secara matematis dituliskan:

$\mathrm{Q}_{\text {in }}=V . I . \operatorname{Cos} \varphi(2.4)$ Pemanas (heater) merupakan salah satu beban listrik yang bersifat resistif atau hambatan murni, oleh karena itu nilai faktor daya sama dengan satu. Sehingga persaman dapat ditulis:

$$
\mathbf{Q}_{\text {in }}=V . I
$$

Dimana

Qin : Daya listrik (Watt)

V : voltase listrik (volt)

I $\quad$ : arus listrik (ampere)

Cos $\varphi$ : faktor daya

\subsection{Perpindahan Panas dengan Perubahan Fasa}

Ketika cairan berkontak dengan permukaan padat yang temperaturnya di atas temperatur jenuh dari cairan, maka pendidihan akan terjadi dengan cepat pada batas (interface) antara cairan-padat. Mode pendidihan dapat dibagi menjadi dua, yaitu pendidihan kolam (pool boiling) dan pendidihan konveksi (convective boiling). 
Pendidikan kolam adalah proses dimana permukaan panas dibasahi oleh sejumlah besar cairan yang diam. Gerakan relatif dari uap yang dihasilkan dan cairan dekat permukaan panas utamanya diakibatkan oleh pengaruh bouyancy dari uap. Namun demikian,cairan secara keseluruhan tetap diam. Sebagaimana dapat dilihat pada gambar 2.8, kurva pendidihan dapat dibagi menjadi enam bagian.

- Pada bagian I, $\Delta \mathrm{T}\left(\Delta \mathrm{T}=\mathrm{T}_{\mathrm{wall}}-\mathrm{T}_{\mathrm{sat}}\right)$ kecil. Pada saat ini uap dihasilkan oleh penguapan cairan menjadi inti gas pada permukaan panas yang terbasahi oleh cairan.

- Pada bagian II, $\Delta \mathrm{T}$ cukup besar. Pada saat ini penambahan gelembung kecil dihasilkan sepanjang permukaan pemanas tetapi kemudian terkondensasi kembali pada daerah di atas cairan superheated.

- Pada bagian III, $\Delta \mathrm{T}$ cukup untuk mempertahankan inti pendidihan dengan menghasilkan gelembung yang terus naik menuju cairan dan tanpa menghiraukan laju kondensasi yang terjadi.

- Pada bagian IV, lapisan uap yang tidak stabil yang terbentuk di atas permukaan pemanas. Pada daerah ini, laju perpindahan panas turun akibat munculnya lapisan uap.

- Pada daerah V, lapisan uap menjadi stabil dan laju perpindahan panas mencapai titik minimum.

- Pada daerah VI, $\Delta \mathrm{T}$ sangat besar dan pendidihan lapisan (film boiling) menjadi stabil sedemikian rupa sehingga radiasi melewati lapisan uap menjadi sangat menentukan dan sangat signifikan dan kemudian meningkatkan laju perpindahan panas seiring dengan naiknya $\Delta \mathrm{T}$.

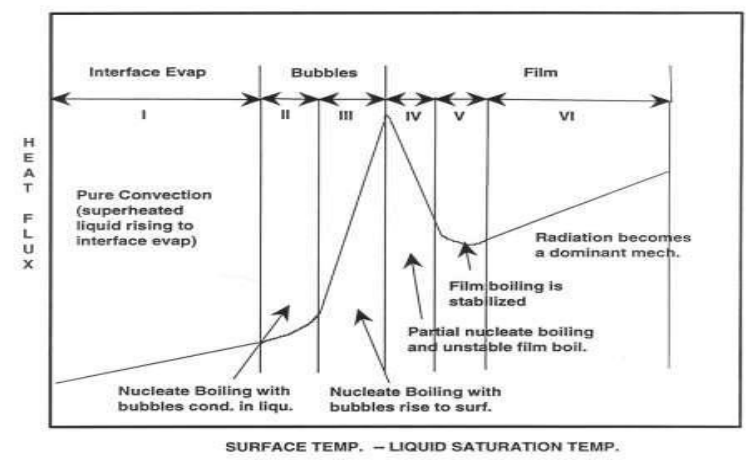

Gambar 2.7. Kurva pendidihan pada pendidihan kolam.

Selain pendidihan kolam, terdapat mode pendidihan konveksi. Pada sebuah aliran internal konveksi paksa yang dipanasi pada permukaan aliran akan muncul gelembung-gelembung pada permukaan aliran tersebut. Gelembung tersebut tumbuh dan terpisah dari permukaan aliran dipengaruhi oleh kecepatan aliran.

Saat terjadi pendidihan gelembung terlihat pada permukaan akan tumbuh dan terbawa ke dalam mainstream liquid. Terdapat kenaikan tajam pada koefisien perpindahan panas ketika masuk pada bubbly flow regime. Dengan naiknya fraksi volume uap, 
gelembung-gelembung bersatu membentuk slug (gelembung yang besar) pada uap. Pada slug flow regime diikuti oleh annular flow regime yang mana liquid membentuk film. Film tersebut bergerak sepanjang permukaan-dalam sementara uap bergerak pada kecepatan tinggi melalui inti pipa. Koefisien perpindahan panas terus meningkat melalui regime bubbly flow dan beberapa annular flow.

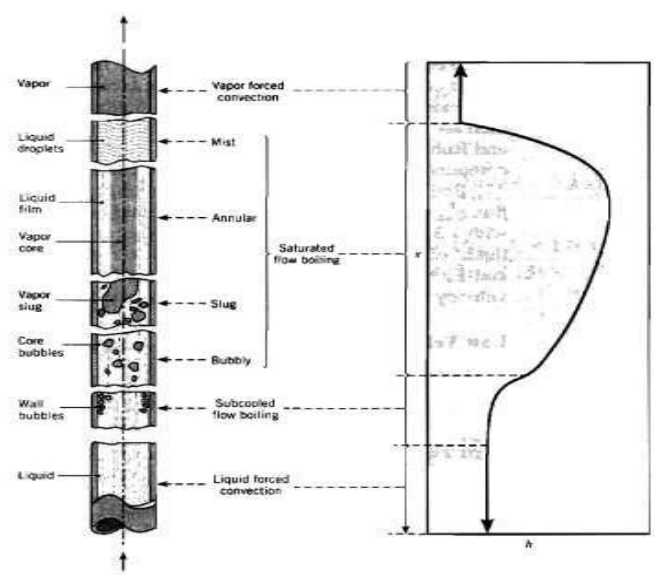

Gambar 2.8. Pendidihan konveksi paksa pada pipa (Incropera, F.P., DeWitt D.P., 2007).

\section{METODE PENELITIAN}

\subsection{Tempat Penelitian}

Penelitian dilakukan di Laboratorium Fenomena Dasar Mesin dan Perpindahan Panas Jurusan Teknik Mesin Fakultas Teknik Universitas HKBP Nommensen

\subsection{Alat Penelitian}

1) Konstruksi :

Tipe : loop thermosyphon

Fluida kerja : R-134a

Jumlah pipa : 3 pipa

2) Bahan :

$$
\text { : pipa tembaga }
$$

- Pipa selubung

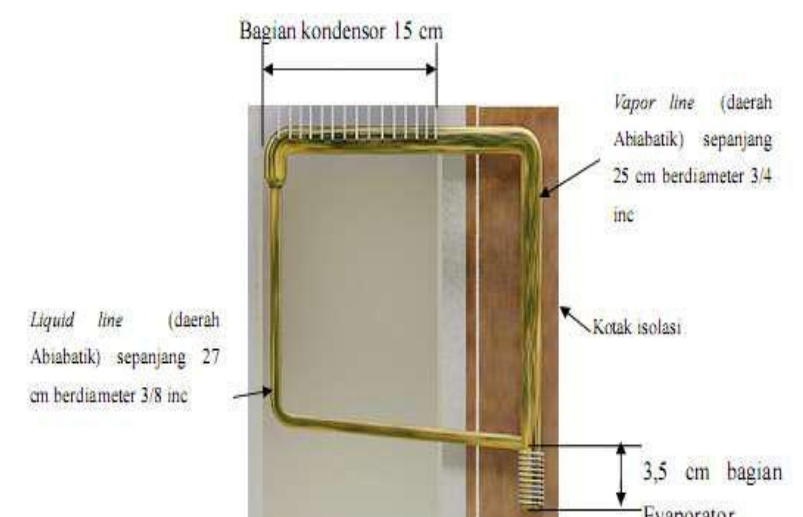




\section{Gambar 3.1. Gambar Loop thermosyphon}

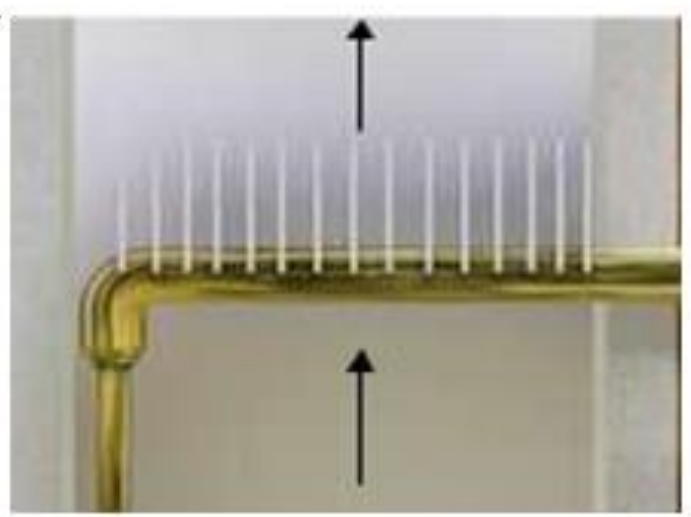

\section{Gambar.3.2. Fins pada Thermosiplon}

- Diameter pipa

: 3/4 inc sepanjang 43,5 cm

b. Fin (sirip)

Dimensi : Panjang : 11,5 cm

Lebar $\quad: 3 \mathrm{~cm}$

Tebal $\quad: 0,1 \mathrm{~cm}$

- Jarak : 0,7 cm

- Jumlah : 15 sirip

- Bahan: alumunium

c. Saluran uji (duct)

1) Pola aliran : crossflow

2) Fluida kerja : udara temperatur ruangan

3) Dimensi:

Received May $4^{\text {th }}$, 2020; Revised June $8^{\text {th }}$, 2020; Accepted June $10^{\text {th }}$, 2020 
- Panjang : $147 \mathrm{~cm}$

- Lebar : $\quad 12 \mathrm{~cm}$

- Tinggi : $12 \mathrm{~cm}$

- Tebal dinding : $: 2,2 \mathrm{~cm}$

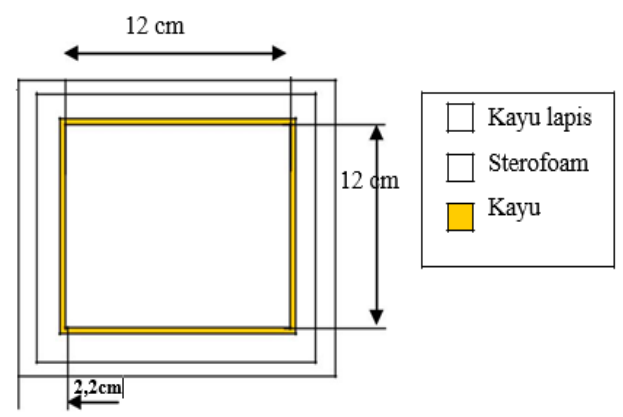

Gambar 3.3. Saluran uji (duct).

Hambatan termal (R) pada dinding dapat dihitung dengan analogi listrik seperti dibawah ini :

Rkayu lapis

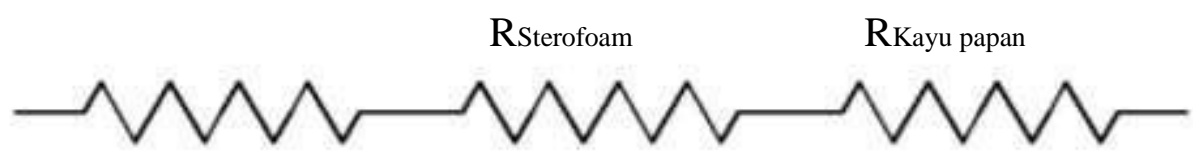

Gambar 3.4. Hambatan termal dinding dalam analogi arus listrik

Sehingga hambatan termal total $\left(\mathrm{R}_{\text {tot }}\right)$ dinding dapat dihitung dengan :

$$
\mathrm{R}_{\text {tot }}=\mathrm{R}_{\text {kayu lapis }}+\mathrm{R}_{\text {sterofoam }}+\mathrm{R}_{\text {kayu papan }}
$$

$\mathrm{R}_{\text {tot }}=8,66 \mathrm{~m} \mathrm{~K} / \mathrm{W} \times 2.10^{-3} \mathrm{~m}+23,8 \mathrm{~m} \mathrm{~K} / \mathrm{W} \times 15.10^{-3} \mathrm{~m}+8,66 \mathrm{~m} \mathrm{~K} / \mathrm{W} \times 5.10^{-3} \mathrm{~m}$

$\mathrm{R}_{\text {tot }}=0,017 m^{2} K / W+0,357 m^{2} K / W+0,043 m^{2} K / W$

$\mathrm{R}_{\text {tot }}=0,417 m^{2} K / W$

d. Instrumentasi dan alat tambahan

1) Instrumentasi :

- Termokopel 


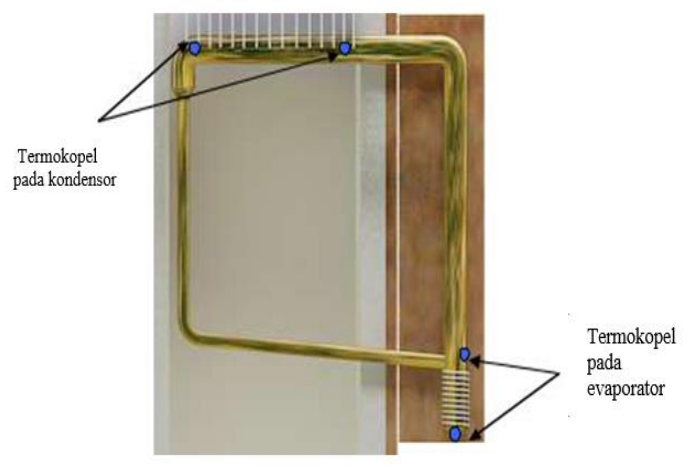

\section{Gambar 3.5. Pemasangan termokopel pada dinding thermosyphon.}

\subsection{Prosedur Penelitian}

Prosedur yang dilakukan dalam pengambilan data berdasarkan variasi daya input pada evaporator thermosyphon, kecepatan aliran udara dalam saluran uji (duct), dan tekanan fluida kerja didalam thermosyphon. Prosedur tersebut terbagi menjadi tiga tahap, tahap persiapan, tahap pengujian awal, dan tahap pengambilan data.

\section{Tahap persiapan}

1. Mengkondisikan vakum thermosyphon dengan pompa vakum dan manifold.

2. Mengisi refrigerant R134a ke dalam thermosyphon dengan menggunakan manifold.

3. Menyusun saluran uji sedemikian rupa serta menempatkan thermosyphon pada saluran uji (duct) seperti pada gambar 3.17.

4. Menempatkan termokopel pada dinding ujung evaporator thermosyphon dan pada dinding ujung kondenser thermosyphon. Sedangkan pada saluran uji, termokopel ditempatkan pada sebelum dan sesudah thermosyphon seperti pada gambar 24.

5. Memasang voltmeter secara paralel dan amperemeter secara seri.

\section{Tahap pengujian awal}

1. Menghidupkan blower dengan memutar dimmer dan mengatur putaran blower hingga menghasilkan kecepatan udara pada saluran uji (duct) sebesar $0,8 \mathrm{~m} / \mathrm{s}$.

2. Menghidupkan pemanas dengan memutar electric regulator.Mengukur temperatur

3. evaporator pipa kalor setelah dialiri listrik untuk

menentukan daya input berapa pemanas mencapai temperatur $40{ }^{\circ} \mathrm{C}$ sebagai daya 1,50 ${ }^{\mathrm{o}} \mathrm{C}$ sebagai daya 2 , dan $60{ }^{\circ} \mathrm{C}$ sebagai daya 3 .

\section{Tahap pengambilan data}


1. Mencatat temperatur udara masuk, temperatur udara keluar, temperatur kondensor, dan temperatur evaporator pada display thermocouple tiap 1 menit selama 60 menit.

2. Mematikan pemanas dan membiarkan fan menyala hingga temperatur evaporator pipa kalor mencapai temperatur ruangan.

3. Mengatur putaran blower hingga menghasilkan kecepatan udara pada saluran uji (duct) sebesar $1 \mathrm{~m} / \mathrm{s}$

4. Mencatat temperatur pada display thermocouple tiap 1 menit selama 60 menit.

5. Mengatur putaran blower hingga menghasilkan kecepatan udara pada saluran uji (duct) sebesar $1,2 \mathrm{~m} / \mathrm{s}$

6. Mengulangi langkah 4

7. Memutar electric regulator untuk mengatur dayanya pada daya 2.

8. Mengatur putaran blower hingga menghasilkan kecepatan udara pada saluran uji (duct) sebesar $0,8 \mathrm{~m} / \mathrm{s}$

9. Mengulangi langkah 3 sampai 5

10. Memutar electric regulator untuk mengatur dayanya pada daya 3.

11. Mengatur putaran blower hingga menghasilkan kecepatan udara pada saluran uji (duct) sebesar $0,8 \mathrm{~m} / \mathrm{s}$

12. Mengulangi langkah 3 dan 5

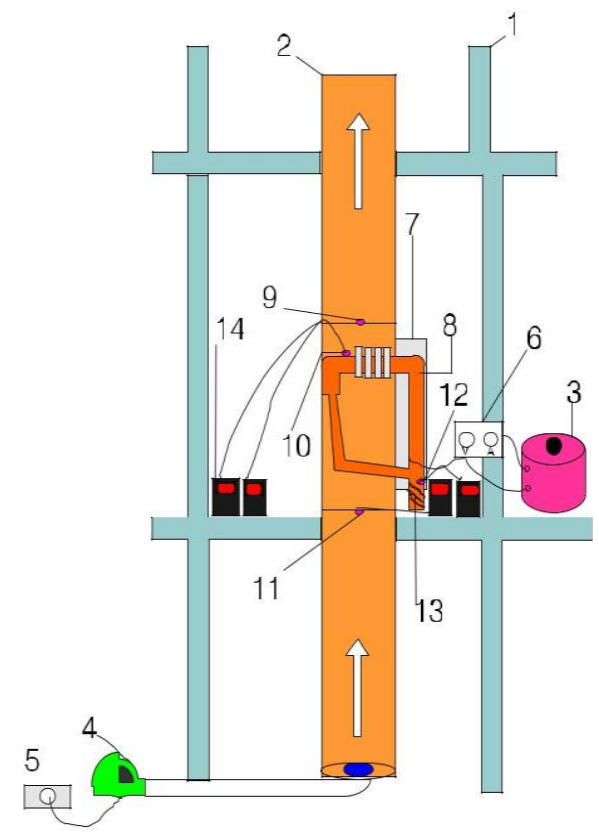

Ket Gambar

2. duct

3. electric regulator

4. blower

$5 . \quad$ dimmer

6. voltmeter dan amperemeter

7. kotak isolasi evaporator

8. Loop thermosyphon

9. termokopel udara keluar dari loop thermosyphon

termokopel ujung loop thermosyphon termokopel udara masuk ke loop thermosyphon termokopel evaporator loop thermosyphon

13. kawat nikelin

14. Display termokopel/ Thermocouple

\section{Gambar 3.6. Skema Alat kerja}

\subsection{Analisisa Data}

Dari data yang diperoleh, selanjutnya dapat dilakukan analisa data yaitu dengan melakukan perhitungan terhadap :

- Efektivitas perpindahan panas loop thermosyphon.

- Hambatan termal loop thermosyphon. 
Efektivitas perpindahan panas dapat dihitung dengan data temperatur udara sebelum dan sesudah melewati thermosyphon, laju aliran massa udara pada saluran uji (duct) dan daya input pada evaporator thermosyphon.. Dari data dan perhitungan tersebut selanjutnya ditampilkan dalam bentuk grafik. Grafik tersebut memperlihatkan tentang:

- Hubungan temperatur pengujian terhadap waktu.

- Hubungan efektivitas perpindahan panas dan hambatan termal terhadap temperatur pada evaporator loop thermosyphon.

- Hubungan efektivitas perpindahan panas terhadap tekanan fluida kerja pada loop thermosyphon.

- Hubungan efektivitas perpindahan panas loop thermosyphon terhadap kecepatan laju udara saluran uji

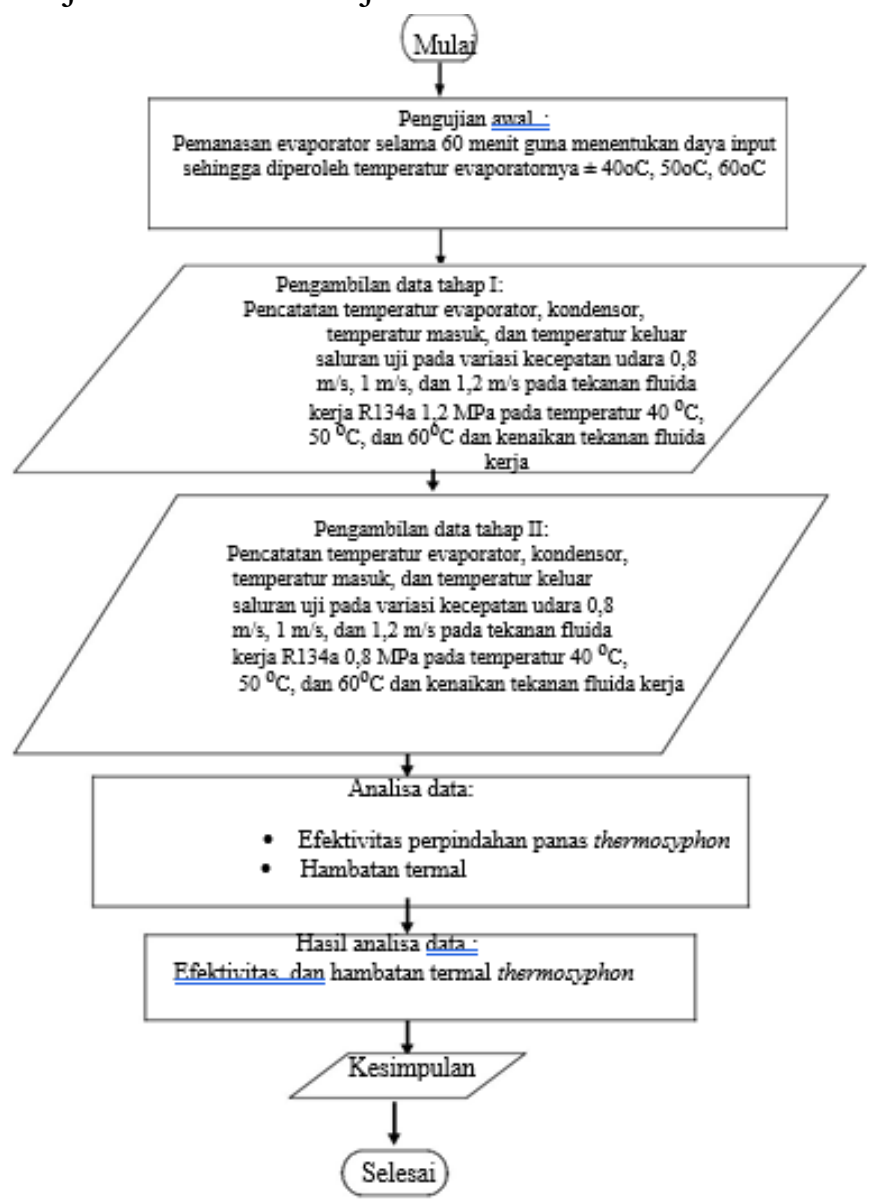

Gambar 3.7. Diagram Alir Penelitian

Penelitian ini didahului dengan persiapan. Persiapan tersebut ditujukan untuk menyiapkan alat dan bahan pengujian sekaligus mencarai daya yang digunakan untuk mencapai temperatur evaporator yang dikehendaki. Langkah tersebut dilanjutkan dengan pengujian tahap I, pada tahap tersebut bertujuan untuk mengetahui nilai efektivitas perpindahan panas dan hambatan termal thermosyphon dengan fluida kerja 
R-134a bertekanan 1,2 Mpa pada temperature $60^{\circ} \mathrm{C}$ dengan variasi kecepatan aliran udara $0,8 \mathrm{~m} / \mathrm{s}, 1 \mathrm{~m} / \mathrm{s}$, dan $1,2 \mathrm{~m} / \mathrm{s}$. Kemudian dilanjutkan pengujian tahap II dengan temperatur evaporator pipa kalor $60^{\circ} \mathrm{C}$ untuk dicari nilai efektivitas perpindahan panas pada thermosyphon dengan fluida kerja R-134a bertekanan 0,8 Mpa dengan variasi kecepatan aliran udara $0,8 \mathrm{~m} / \mathrm{s}, 1 \mathrm{~m} / \mathrm{s}$, dan $1,2 \mathrm{~m} / \mathrm{s}$. Setelah data pengujian terkumpul dilakukan analisa data dan akhirnya menghasilkan kesimpulan tentang karakteristik perpindahan panas dan hambatan termal pipa kalor pada temperatur $\leq$ $60^{\circ} \mathrm{C}$.

\subsection{Variasi Pengujian Thermosyphon}

Tabel 3.1. Variasi pengujian.

\begin{tabular}{|c|c|c|c|c|}
\hline No & $\begin{array}{c}\text { Tekanan Fluida } \\
\text { Kerja }\end{array}$ & Fluida Kerja & $\begin{array}{c}\text { Temp Maks } \\
\text { Evaporator }\end{array}$ & Kecepatan Aliran \\
\hline $\mathbf{1}$ & & R-134a & $40^{\circ} \mathrm{C}$ & $0,8 \mathrm{~m} / \mathrm{s}$ \\
\hline $\mathbf{2}$ & $0,8 \mathrm{Mpa}$ & R-134a & $40{ }^{\circ} \mathrm{C}$ & $1 \mathrm{~m} / \mathrm{s}$ \\
\hline $\mathbf{3}$ & & R-134a & $40{ }^{\circ} \mathrm{C}$ & $1,2 \mathrm{~m} / \mathrm{s}$ \\
\hline $\mathbf{4}$ & & R-134a & $50^{\circ} \mathrm{C}$ & $0,8 \mathrm{~m} / \mathrm{s}$ \\
\hline $\mathbf{5}$ & $0,8 \mathrm{Mpa}$ & R-134a & $50{ }^{\circ} \mathrm{C}$ & $1 \mathrm{~m} / \mathrm{s}$ \\
\hline $\mathbf{6}$ & & R-134a & $50{ }^{\circ} \mathrm{C}$ & $1,2 \mathrm{~m} / \mathrm{s}$ \\
\hline $\mathbf{7}$ & & R-134a & $60^{\circ} \mathrm{C}$ & $0,8 \mathrm{~m} / \mathrm{s}$ \\
\hline $\mathbf{8}$ & $0,8 \mathrm{Mpa}$ & R-134a & $60^{\circ} \mathrm{C}$ & $1 \mathrm{~m} / \mathrm{s}$ \\
\hline $\mathbf{9}$ & & R-134a & $60{ }^{\circ} \mathrm{C}$ & $1,2 \mathrm{~m} / \mathrm{s}$ \\
\hline $\mathbf{1 0}$ & & R-134a & $40^{\circ} \mathrm{C}$ & $0,8 \mathrm{~m} / \mathrm{s}$ \\
\hline $\mathbf{1 1}$ & $1,2 \mathrm{Mpa}$ & R-134a & $40{ }^{\circ} \mathrm{C}$ & $1 \mathrm{~m} / \mathrm{s}$ \\
\hline $\mathbf{1 2}$ & & R-134a & $40{ }^{\circ} \mathrm{C}$ & $1,2 \mathrm{~m} / \mathrm{s}$ \\
\hline $\mathbf{1 3}$ & & R-134a & $50^{\circ} \mathrm{C}$ & $0,8 \mathrm{~m} / \mathrm{s}$ \\
\hline $\mathbf{1 4}$ & $1,2 \mathrm{Mpa}$ & R-134a & $50{ }^{\circ} \mathrm{C}$ & $1 \mathrm{~m} / \mathrm{s}$ \\
\hline $\mathbf{1 5}$ & & R-134a & $50{ }^{\circ} \mathrm{C}$ & $1,2 \mathrm{~m} / \mathrm{s}$ \\
\hline $\mathbf{1 6}$ & & R-134a & $60^{\circ} \mathrm{C}$ & $0,8 \mathrm{~m} / \mathrm{s}$ \\
\hline $\mathbf{1 7}$ & $1,2 \mathrm{Mpa}$ & R-134a & $60^{\circ} \mathrm{C}$ & $1 \mathrm{~m} / \mathrm{s}$ \\
\hline $\mathbf{1 8}$ & & R-134a & $60{ }^{\circ} \mathrm{C}$ & $1,2 \mathrm{~m} / \mathrm{s}$ \\
\hline
\end{tabular}

\section{HASIL DAN PEMBAHASAN}

\subsection{Karakteristik Perpindahan Panas APKLT Bertekanan 0,8 MPa}

Terlihat bahwa efektifitas APKLT bertekanan 0,8 MPa lebih besar dibandingkan alat penukar kalor loop thermosyphon tanpa fluida kerja (APKTF) untuk semua variasi kecepatan udara dan suhu evaporator yang sama. Dengan APKLT 0,8 $\mathrm{MPa}$, efektivitas perpindahan panasnya meningkat sekitar 1,5-2 kali dari efektivitas perpindahan panas APKTF. Efektivitas APKLT 0,8 Mpa berkisar antara 22-35\%, sedangkan efektivitas APKTF berkisar antara 14-21\%. Mekanisme perpindahan panas yang terjadi pada APKLT adalah panas dari sumber panas ditransfer ke bagian yang 
lebih dingin melalui konduksi, sedangkan mekanisme perpindahan panas pada APKLT selain terjadi secara konduksi juga terjadi secara konveksi berupa perubahan fasa dan sirkulasi fluida atau refrigerant yang terdapat dalam APLKT.

Terlihat efektifitas APKLT meningkat seiring dengan peningkatan suhu evaporator dari $40^{\circ} \mathrm{C}$ ke $50^{\circ} \mathrm{C}$. Hal ini terjadi karena semakin tinggi suhu evaporator maka hambatan termal semakin rendah, oleh karena itu panas yang ditransfer dari evaporator menuju kondensor semakin tinggi. Pada suhu evaporator $60^{\circ} \mathrm{C}$ tidak ada kenaikan yang signifikan pada efektifitas perpindahan panas APKLT bertekanan 0,8 $\mathrm{MPa}$. Hal ini terjadi karena pada suhu evaporator $60^{\circ} \mathrm{C}$ hambatan termalnya meningkat kembali sehingga panas yang ditransfer dari evaporator menuju kondensor mulai terhambat. Akibatnya tidak ada kenaikan efektifitas perpindahan panas yang signifikan.

Hambatan termal yang meningkat kembali pada saat suhu evaporator $0^{\circ} \mathrm{C}$ disebabkan oleh adanya fenomena saat pengujian bahwa suhu evaporator rata-rata lebih besar dari temperatur jenuh refrigerant di bagian evaporator yaitu sekitar $7^{\circ} \mathrm{C}$ (lihatTabel 4.1). Jika temperatur rata-rata di evaporator jauh lebih tinggi dari $\mathrm{T}_{\text {sat }}$, akibatnya akan terdapat lebih banyak uap refrigerant $\mathrm{R} 134$ a di evaporator sehingga refrigerant cair dari kondensor akan sulit bersirkulasi. Jika sirkulasi refrigerant sulit terjadi, maka hambatan termal dari APKLT pada kondisi ini akan meningkat kembali.

Tabel 4.1. Temperatur rata-rata dan temperatur jenuh fluida kerja di bagian evaporator APKLT 0,8 MPa

\begin{tabular}{|c|c|c|c|c|}
\hline \multirow{2}{*}{$\begin{array}{c}\text { Suhu } \\
\text { setingan }\end{array}$} & \multicolumn{3}{|c|}{$\begin{array}{c}\text { Temperatur } \\
\text { jenuh }\end{array}$} \\
\cline { 2 - 5 } & $\begin{array}{c}\text { Kecepatan } \\
\text { udara }\end{array}$ & $\begin{array}{c}\text { Kecepatan } \\
\text { udara } \\
\text { Evaporator }\end{array}$ & $\begin{array}{c}\text { Kecepatan } \\
\text { udara }\end{array}$ & $\begin{array}{c}\text { Fluida kerja } \\
\text { pada evaporator }\end{array}$ \\
\hline $40^{\circ} \mathrm{C}$ & $42,64^{\circ} \mathrm{C}$ & $40,54^{\circ} \mathrm{C}$ & $40^{\circ} \mathrm{C}$ & $38^{\circ} \mathrm{C}$ \\
\hline $50^{\circ} \mathrm{C}$ & $51,11^{\circ} \mathrm{C}$ & $50,25^{\circ} \mathrm{C}$ & $50,13^{\circ} \mathrm{C}$ & $50^{\circ} \mathrm{C}$ \\
\hline $60^{\circ} \mathrm{C}$ & $62,08^{\circ} \mathrm{C}$ & $61,37^{\circ} \mathrm{C}$ & $59,32^{\circ} \mathrm{C}$ & $55,5^{\circ} \mathrm{C}$ \\
\hline
\end{tabular}

Bahwa kecepatan aliran udara yang akan dipanaskan berpengaruh terhadap efektifitas perpindahan panas APKLT bertekanan 0,8 MPa. Semakin besar kecepatan aliran udara yang akan dipanaskan menyebabkan penurunan efektifitas APKLT bertekanan 0,8 MPa. Terlihat bahwa pada kecepatan aliran udara yang semakin besar akan menyebabkan efektifitas perpindahan panas semakin kecil untuk semua variasi suhu evaporator yang dilakukan pada pengujian ini. 


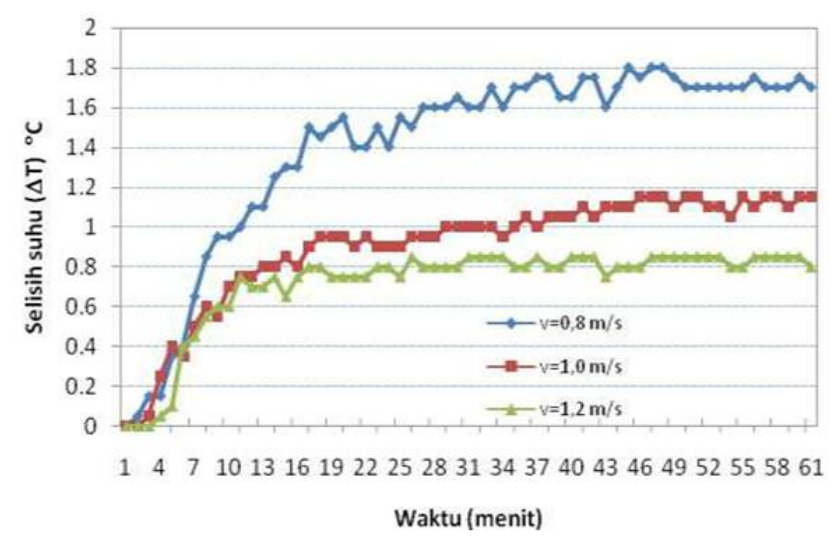

Gambar 4.2. Selisih suhu $(\Delta T)$

udara setelah melewati APKLT dengan fluida kerja R-134 bertekanan 0,8 MPa seiring dengan meningkatnya kecepatan aliran udara yang akan dipanasi.

Penyebab turunnya efektifitas perpindahan panas pada APKLT karena peningkatan kecepatan aliran udara menyebabkan penurunan suhu udara setelah melewati APKLT sebagaimana dapat dilihat pada Gambar 4.4 Penurunan suhu udara keluaran atau suhu udara setelah melewati APKLT menyebabkan nilai perbedaan suhu sebelum dan suhu sesudah melewati APKLT ( $\Delta \mathrm{T}$ ) menurun, sehingga nilai laju perpindahan panas aktual menurun, sesuai dengan persamaan $Q_{a}=m_{a} c_{p a} \Delta \mathrm{T}$, dimana nilai kenaikan $m_{a}$ tidak sebanding dengan penurunan nilai $\Delta \mathrm{T}$ yang akan menyebabkan nilai $Q_{a}$ menurun, sehingga efektifitas menurun.

\subsection{Karakteristik Perpindahan Panas APKLT Bertekanan 1,2 MPa}

Dapat dilihat pula bahwa tekanan fluida kerja APKLT mempunyai pengaruh pada efektifitas perpindahan panas APKLT. Efektivitas perpindahan panas APKLT bertekanan 1,2 MPa lebih besar dibandingkan APKLT fluida kerja R134a bertekanan 0,8 MPa pada kecepatan aliran udara dan suhu evaporator yang sama. Fenomena ini berlaku untuk semua variasi kecepatan aliran udara dan suhu evaporator. Penyebabnya adalah bahwa pada APKLT 1,2 $\mathrm{MPa}$ memiliki hambatan termal lebih rendah dibandingkan APKLT 0,8 MPa sehingga pada APKLT 1,2 MPa panas yang ditransfer dari evaporator menuju kondensor lebih besar dibandingkan dengan APKLT 0,8 MPa. Dapat dilihat pula seiring bertambahnya suhu pada evaporator maka efektifitas perpindahan panas pada APKLT 1,2 MPa makin bertambah, hal ini terjadi karena semakin meningkatnya suhu evaporator maka hambatan termal semakin menurun.

Perbedaan hambatan termal APKLT 1,2 MPa dengan APKLT 0,8 MPa pada variasi suhu evaporator 40,50 , dan $60^{\circ} \mathrm{C}$. Hambatan termal pada APKLT bertekanan 1,2 $\mathrm{MPa}$ lebih rendah dibandingkan hambatan termal pada APKLT 0,8 MPa. Hambatan termal APKLT bertekanan 0,8 MPa berkisar antara 0,3-0,45 ${ }^{\circ} \mathrm{C} / \mathrm{W}$ sedangkan hambatan termal APKLT bertekanan 1,2 $\mathrm{MPa}$ berkisar antara 0,08-0,4 ${ }^{\mathrm{O}} \mathrm{C} / \mathrm{W}$. Semakin tinggi 
suhu evaporator menyebabkan hambatan termal APKLT menurun sehingga perpindahan panas menjadi lebih efektif. Pada suhu evaporator $60^{\circ} \mathrm{C}$, pada APKLT bertekanan 0,8 MPa terjadi peningkatan hambatan termal sedangkan pada APKLT bertekanan 1,2 MPa terjadi penurunan hambatan termal. Hal ini terjadi karena pada suhu evaporator $60^{\circ} \mathrm{C}$, pengujian suhu evaporator rata-rata pada APKLT 1,2 MPa mendekati nilai temperatur jenuh refrigerant di bagian evaporator (lihat Tabel 4.2) sedangkan pada APKLT 0,8 MPa jauh lebih tinggi dimana hambatan termal untuk APKLT bertekanan $0,8 \mathrm{MPa}$ dan pipa kosong. Jika temperatur rata-rata di evaporator mendekati dari $\mathrm{T}_{\text {sat }}$, maka refrigerant cair dari kondensor akan lebih mudah bersirkulasi. Jika sirkulasi refrigerant terjadi, maka hambatan termal dari APKLT 1,2 MPa pada kondisi ini masih menurun.

\section{Tabel 4.2. Temperatur rata-rata dan temperatur jenuh fluida kerja di bagian evaporator APKLT 1,2 MPa}

\begin{tabular}{|c|c|c|c|c|}
\hline \multirow{2}{*}{$\begin{array}{c}\text { Suhu } \\
\text { setingan } \\
\text { evaporator }\end{array}$} & $\begin{array}{c}\text { Kecepatan } \\
\text { udara } \\
\mathbf{0 , 8} \mathbf{~ m} / \mathbf{s}\end{array}$ & $\begin{array}{c}\text { Kecepatan } \\
\text { udara } \\
1,0 \mathbf{~ m} / \mathbf{s}\end{array}$ & $\begin{array}{c}\text { Kecepatan } \\
\text { udara } \\
\mathbf{1 , 2} \mathbf{~ m} / \mathbf{s}\end{array}$ & $\begin{array}{c}\text { Jenuh } \\
\text { fluida kerja pada } \\
\text { evaporator }\end{array}$ \\
\hline $40^{\circ} \mathrm{C}$ & $40,58^{\circ} \mathrm{C}$ & $40,54^{\circ} \mathrm{C}$ & $40^{\circ} \mathrm{C}$ & $46^{\circ} \mathrm{C}$ \\
\hline $50^{\circ} \mathrm{C}$ & $51,61^{\circ} \mathrm{C}$ & $50,25^{\circ} \mathrm{C}$ & $50,13^{\circ} \mathrm{C}$ & $50,66^{\circ} \mathrm{C}$ \\
\hline $60^{\circ} \mathrm{C}$ & $62,28^{\circ} \mathrm{C}$ & $57,53^{\circ} \mathrm{C}$ & $57,55^{\circ} \mathrm{C}$ & $59,96^{\circ} \mathrm{C}$ \\
\hline
\end{tabular}

Gambar 4.2 juga menunjukkan pengaruh kecepatan aliran udara terhadap efektifitas perpindahan panas pada berbagai suhu evaporator untuk tekanan fluida kerja 1,2 $\mathrm{MPa}$. Pada kecepatan aliran udara yang semakin besar akan menyebabkan efektifitas perpindahan panas semakin kecil untuk semua variasi suhu evaporator yang dilakukan pada pengujian ini.

Penyebab turunnya efektifitas perpindahan panas pada APKLT karena peningkatan kecepatan aliran udara menyebabkan penurunan suhu udara setelah melewati APKLT Penurunan suhu udara keluaran atau suhu udara setelah melewati APKLT menyebabkan nilai perbedaan suhu sebelum dan suhu sesudah melewati APKLT

$(\Delta \mathrm{T})$ menurun, sehingga nilai laju perpindahan panas aktual menurun, sesuai dengan persamaan $Q_{a}=m_{a} \quad c{ }_{p a} \Delta \mathrm{T}$, dimana nilai kenaikan $m_{a}$ tidak sebanding dengan penurunan nilai $\Delta \mathrm{T}$ yang akan menyebabkan nilai $Q_{a}$ menurun, sehingga efektifitas menurun. Fenomena ini yang terjadi pada tekanan fluida kerja 1,2 MPa sama dengan pada tekanan fluida kerja $0,8 \mathrm{MPa} .35$

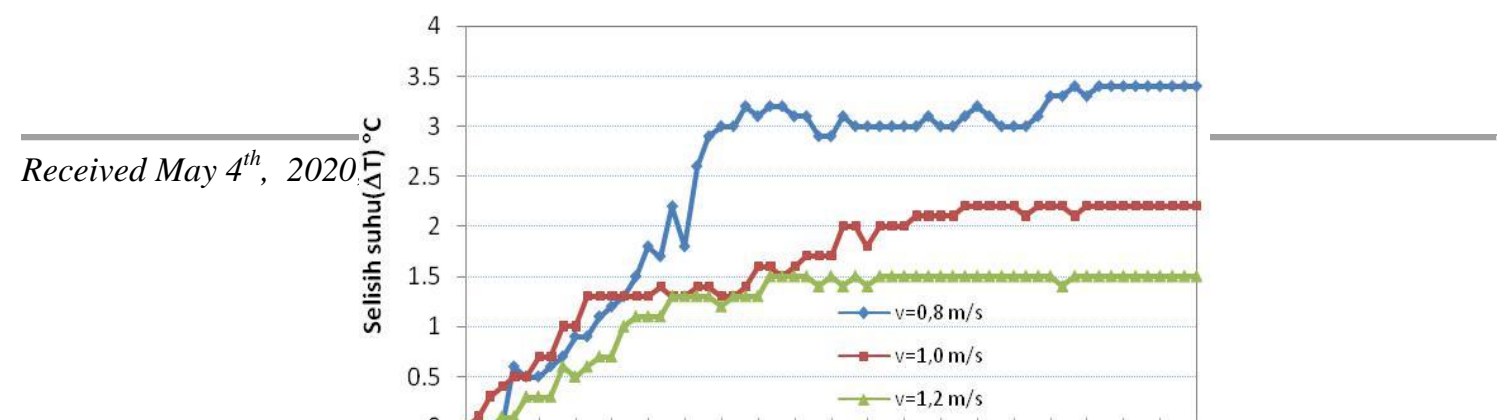




\section{Gambar 4.2}

Gambar 4.2. Selisih suhu $(\Delta \mathrm{T})$ udara setelah melewati APKLT fluida kerja R-134a bertekanan 1,2 MPa untuk berbagai kecepatan aliran udara yang akan dipanasi.

\section{KESIMPULAN DAN SARAN}

1. Peningkatan suhu evaporator (heat source) akan mempengaruhi efektifitas perpindahan panas dan hambatan termal pada APKLT

2. Efektifitas perpindahan panas pada APKLT yang berfluida kerja R134a menurun seiring peningkatan kecepatan aliran udara pada saluran $(d u c t)$.

3. Tekanan fluida kerja berpengaruh terhadap efektifitas perpindahan panas pada APKLT. Semakin tinggi tekanan R134a maka efektifitas semakin meningkat. Efektivitas perpindahan panas APKLT fluida kerja bertekanan 1,2 MPa sekitar 30-68\% dan lebih tinggi dibandingkan efektivitas perpindahan panas APKLT fluida kerja bertekanan 0,8 MPa sekitar 22-35\%. Hambatan termal APKLT bertekanan 0,8 $\mathrm{MPa}$ sekitar 0,3-0,45 ${ }^{\circ} \mathrm{C} / \mathrm{W}$ dan lebih besar dari hambatan termal APKLT bertekanan 1,2 MPa sekitar 0,08-0,4 ${ }^{\circ} \mathrm{C} / \mathrm{W}$.

\section{DAFTAR PUSTAKA}

(http://en.wikipedia.org/wiki/Ethanol dilihat pada tanggal 9 Desember 2009). Anonim,gas

Encyclopaedia,(http://encyclopedia.airliquide.com/encyclopedia.asp?GasID=141 dilihat pada tanggal 9 Desember 2009).

Bejan, Andrian and Allan D. Kraus., 2003, Heat Transfer Handbook, John wiley and Sons, New Jersey

Behnia, M., Morrison, G.L.,Paramasivam, S, Heat Transfer and flow in inclined open thermosyphons, School of Mechanical Engineering, University of New South Wales, Kensington, Sydney NSW, Australia

Holman, J.P., 1997, Perpindahan Kalor, Jakarta

Incropera, F.P., DeWitt D.P., 2007, Fundamental of Heat and Mass Transfer, 6th Ed, John Willey and Sons, New York.

(http://books.google.co.id Irvine,F.T, Hartnett P.J., 1973, Advances in Heat Transfer, Academic Press, Volume 9, New York. 
Jouhara H, O. Martinet, A.J. Robinson., 2008, Experimental Study of Small Diameter Thermosyphons Charged with Water, FC-84, FC-77 \& FC-3283, European thermal sciences Conference, Nethrlands.

Meena, P. and S. Rittidech., 2008, Comparisons of Heat Transfer Performance of a Closed-looped Oscillating Heat Pipe and Closed-looped Oscillating Heat Pipe with Check Valves Heat Exchangers, American J. of Engineering and Applied Sciences 1 (1): 7-11.

Meena, P., S. Rittidech and N. Poomsa-ad., 2006, Closed-loop oscillating heat-pipe with check valves (CLOHP/CVs) air-preheater for reducing relative humidity in drying systems, Faculty of Engineering, Mahasarakham University, Thailand.

Meng-Chang Tsai., Chih-Sheng Hsieh., Shung-Wen Kang., 2007, Experimental Study of a Loop Thermosyphon Using Methanol as Working Fluid,

International Heat Pipe Conference (14th IHPC), Florianópolis, Brazil, April 22-27, 2007.

Meyer, A., Dobson, R.T., 2006, A Heat Pipe Heat Recovery Heat Exchanger for a Mini-Drier, Journal of Energy in Southern Africa, Vol 17 No 1.

Pal, A., Joshi, Y., Beitelmal, A. H., Patel, C. D. and Wenger, T., 2002, Design and Performance Evaluation of a Compact Thermosyphon, Proceedings of the United Engineering Foundation, Thermes, Santa Fe, New Mexic 